\title{
Introduction
}

\section{We Are the Children of the Transformation: Post-communist Children's Cultures in Central, Eastern, and Southeast Europe}

This special issue of Miscellanea of Posttotalitariana Wratislaviensia inevitably has both a personal and professional significance for its editors and most of the contributors as east-central Europeans whose childhood was marked by the experience of the collapse of communism and its consequences, and as scholars exploring its influence on children's culture, which they once (hopefully) enjoyed without the (burdensome) mediation of the theoretical apparatus they apply to it today. Hence let us begin with a personal reminiscence. In 1986, when Justyna was 11 years old, she and her mother went to Leuven, Belgium, to visit the family of her father's colleague. It was Justyna's first trip abroad and it was preceded by the anxious waiting for passports and official permission to travel. Her most vivid memory from that trip is a massive pink wall of Barbie doll boxes filling the shelves in a Mattel shop from top to bottom. It is worth pointing out here that Western toys like Barbie or Lego were available only at Pewex (Przedsiębiorstwo Eksportu Wewnętrznego - Internal Export Company) shops, selling Western goods (e.g. Coca Cola, jeans, genuine chocolate)

Address: Institute of English Studies, ul. Kuźnicza 22, 50-138 Wrocław; Institute of Slavic Studies, ul. Pocztowa 9, 53-313 Wrocław; E-mail: justyna.deszcz-trybubczak@uwr.edu.pl, mateusz. swietlicki@uwr.edu.pl. 
for hard currency, usually US dollars. Justyna did get her first Barbie from the shop in Leuven, and her Belgian friends, most probably not really believing that there could be a European country with limited access to Barbie dolls, gave her several used Barbies, all of which made her popular with her Polish friends on her return to Poland. In Globalization and the Transformation of Media Cultures in the New Europe (2009), Anikó Imre notes that such recollections about imported Western goods be it toys, foods or one's first pair of Levi's jeans - "transcend and question national lines of affinity and community", thereby generating "postcommunist memory communities" beyond official borders. ${ }^{1}$

This "toy deprivation" experienced by Polish children, and most probably also by their peers from what Jacques Rupnik famously refers to as "the other Europe", officially ended with the 1989-91 democratic velvet revolutions, which initiated the liberation of Central, East, and South-East Europe from the Soviet regime. Yet, as the teenage protagonist of Marzena Sowa and Sylvain Savoia's graphic series about Marzi reflects on the abrupt and awkward ${ }^{3}$ emergence of a supposedly better reality than the economic misery behind the Iron Curtain, the promise of a new life in fact implied the emergence of new local inequalities. Neil Lazarus thus defines what Marzi realises only intuitively: "in the post-Soviet contexts, the full implications of the fact that liberation from 'actually existing' socialism has been liberation into the world-system of 'actually existing' capitalism are now having to be confronted. For this latter is a world-system, already and in principle deeply uneven, and now undergoing profound contraction and structural crisis besides". ${ }^{4}$ Relating Lazarus's argument to the contexts of childhood and children's culture, born ten years before the end of communism in Poland, Marzi embodies the ambivalent sensibilities of "a generation of people whose childhood and youth are rooted in the extinct world of communism, and whose maturation into adulthood coincided with an accelerated

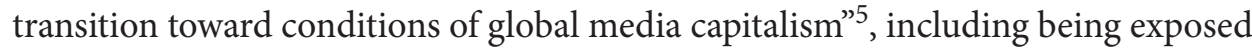
to global (read: mostly Western) children's culture. Another member of the generation experiencing the transition, Marzena Sowa herself voices the mixture of hope, apprehension, and what Imre refers to as "desperate scrambling for an epistemological paradigm" ${ }^{\prime}$, by making Marzi compare her desire to grow up and be able to wear elegant ladies footwear to how Poland needs to mature to fit "freedom and what awaits us", in other words, to mature "to wear non-communist shoes", which

${ }^{1}$ A. Imre, Globalization and the Transformation of Media Cultures in the New Europe, Cambridge, MA 2009, p. 76.

2 J. Rupnik, The Other Europe, London 1988, p. 4.

3 A. Imre, op. cit., p. 3.

${ }^{4}$ N. Lazarus, "Spectres haunting: Postcommunism and postcolonialism," Journal of Postcolonial Writing 2012, vol. 48, no. 2, p. 121.

5 A. Imre, op. cit., p. 65.

${ }^{6}$ Ibid., p. 4.

${ }^{7}$ M. Sowa, S. Savoia, Nie ma wolności bez solidarności, Warszawa 2011, p. 25 (translation J.D-T.). 
has meant both dealing with the legacy of communism and a training for life in a capitalist consumer-driven society.

Eleven years after Justyna's experience with Barbies, the nine-year-old Mateusz had his own experience with the legendary doll: he saw Aqua's "Barbie Girl" on VIVA. Despite its risqué lyrics, the colorful (and extremely campy) music video depicting the life of Barbie and Ken became particularly popular with children. By 1997 Barbie dolls were just one of many Western toys available in Polish toy shops. Contrary to Justyna's school years, Mateusz's childhood was also defined by the more recent phenomena of Western pop-culture, especially by the release of Disney movies (such as The Lion King, 1994 and Pocahontas, 1996), the publication of the first volume of J.K. Rowling's Harry Potter series (Harry Potter and the Philosopher's Stone, 2000), the premiere of music videos by The Spice Girls and Britney Spears, the appearance of gadgets like Tamagotchi (1996) and iPod (2001), as well as the growing importance of the Internet (MySpace, 2003). Yet he could still constantly feel the shadow of the communist legacy not only coming from the generation of his parents and teachers but also constantly present on Polish TV. For instance, in the 1990s most Polish households still did not have satellite television with Western children's channels such as Cartoon Network, but almost every child watched the evening cartoon called Wieczorynka (broadcast on TVP1 before Wiadomości $[\mathrm{News}]^{8}$ ). On some days, usually on Fridays, Wednesdays, and Sundays, the cartoons included The Smurfs, Disney's Adventures of the Gummi Bears, and The Flinstones, but on each of the other weekdays mostly Krtek, Bolek and Lolek, Miś Uszatek, Reksio, and Nu, pogodi!, all produced in the Eastern Bloc before the collapse of communism.

In this issue of Miscellanea of Posttotalitariana Wratislaviensia we are interested in exploring how children's culture produced in the formerly Soviet-ruled countries has addressed the experience of post-communist subjects, both those who have lived in the former regime and those for whom it is "an inherited memory": today, no one under 28 was even alive while communist rule in central-east Europe still existed; no one under 35 or so has any meaningful memories of it. While adult culture of the post-communist period has been subject to intense international critical efforts to understand and theorize how it has addressed "the collective [and individual for that matter] shock that Eastern Europeans have had to process since the end of communism", research into post-communist cultural production for children, however intense in particular national contexts, remains dispersed and inaccessible at the supranational level. Granted, owing to the limited scope of a scholarly journal, the contributions to the present volume can capture only selective engagements with the thematic, generic, and media diversity of post-communist children's culture. Yet, while we remain critically aware of the highly problematic nature of post-communism as an "umbrella term lumping together societies which share an experi-

\footnotetext{
${ }^{8}$ Wieczorynka (Dobranocka) was broadcast from the 1950s until 2013.

${ }^{9}$ A. Imre, op. cit., p. 36.
} 
ence of communist political regimes but have different local histories and distinct understandings of their situation, aims, roles and prospects in the global world"10, we hope to initiate a more wide-ranging discussion on post-1989 children's culture in east-central Europe as reflecting a shared experience, regional interactions, and nuances of the distinct paths each of the countries in question have taken since 1989.

A useful springboard for such a discussion can be found in Imre's Globalization and the Transformation of Media Cultures in the New Europe (2009), already quoted above. Relying among others on the concepts of restorative and reflective nostalgia ${ }^{11}$, the culture of memory ${ }^{12}$, and "pop cosmopolitanism"13, Imre scrutinizes post-1989 children's culture - both native (Krtek, the "Little Mole" franchise, Bolek and Lolek animated series) and imported (Westerns, Jurassic Park) - as a screen onto which east-central Europeans have projected "compensatory [often conflicting] desires for full Europeanness" 14 and for protecting indigenous culture from the corrupting and infantilizing influence of Western entertainment, and especially Hollywood and Disney. ${ }^{15}$ As she further comments, "since the early 1990s, dinosaurs, cowboys, and Indians have found a peaceful way to coexist in the all-incorporating post-communist nostalgia market. Western-themed restaurants, bars, and shops are as ubiquitous in post-Soviet towns as dinosaur toys are on store shelves and mini-Jurassic theme parks on the outskirts of cities". ${ }^{16}$ Simultaneously, the entertainment culture of communism, including children's animation of high artistic and intellectual quality, "has been gathered by the collective work of individuals and found its way to fan sites, YouTube, and other file-sharing Internet archives"17, thereby joining global culture flows. This "curative nostalgia" 18 for past programmes has also resulted in developing tie-ins related to particular brands, such as stationery, stuffed animals, and clothes. ${ }^{19}$ All these remnants, revivals and reboots of communist children's culture certainly encourage intergenerational engagement with past childhoods, and perhaps of a different kind than the expressions of nostalgia that Maria Todorova calls "monumentalization", that is "the proliferation of theme parks, sculpture gardens, and museum exhibits" ${ }^{20}$, often intended as family destinations. It

${ }^{10} \mathrm{M}$. Tlostanova, "Postsocialist $\neq$ postcolonial? On post-Soviet imaginary and global coloniality," Journal of Postcolonial Writing 2012, vol. 48, no. 2, p. 131.

11 S. Boym, The Future of Nostalgia, New York 2001, p. 33.

12 A. Huyssen, "Present Pasts: Media, Politics, Amnesia," Public Culture 2001, vol. 12, no. 1, p. 23.

${ }^{13}$ H. Jenkins, Fans, Bloggers and Gamers: Media Consumers in a Digital Age, New York 2005, pp. $155-156$.

\footnotetext{
${ }^{14}$ A. Imre, op. cit., p. 84.

${ }^{15}$ Ibid., pp. 68-69.

16 Ibid., p. 64.

17 Ibid., p. 70.
}

${ }_{18}$ M. Todorova, "Introduction: From Utopia to Propaganda and Back," [in:] Post-Communist Nostalgia, ed. M. Todorova and Z. Gille, New York and London 2010, p. 8.

${ }^{19}$ Ibid., p. 70.

${ }^{20}$ Ibid., p. 8. 
suffices to mention the recently-opened Centrum Historii Zajezdnia (History of the Bus/Tram Depot Centre) in Wrocław, Poland, where children and adults spend time among communist memorabilia, including toys. In this light, Imre rightly wonders about the consequences of the encounter between "the culture of the mole with the culture of the dinosaur" 21 : What old loyalties have survived and which new identifications have been nourished?

This question reverberates in three contributions to Fairy-Tale beyond Disney: International Perspectives (2016), edited by Jack Zipes, Pauline Greenhill, and Kendra Magnus-Johnston. ${ }^{22}$ In "'To Catch Up and Overtake Disney?' Soviet and Post-Soviet Fairy-Tale Films", Marina Balina and Birgit Beumers point out the dearth of fairytale films, including productions for young audiences, in the years of perestroika (1986-1991) and in the 1990s, largely because of the crisis in the film industry. ${ }^{23}$ Yet it made a fresh, if slow start in animation and especially through the project "The Mountain of Gems", which "has created a platform for a new generation of animators. In a sense, both wish to revive Russian folk heritage through the medium of cinema". ${ }^{24}$ Balina and Beumers stress the project's "concern with stories that encompass a range of ethnic groups and regions in an attempt to forge a new, postSoviet national identity for the Russian Federation". ${ }^{25}$ In contrast, as indicated in the contributions by Peter Hames (on the Czech and Slovak fairy-tale films) and Justyna Deszcz-Tryhubczak and Marek Oziewicz (on Polish fairy-tale films and TV shows), in the Czech and Slovak Republics, as well as in Poland, the fairy-tale genre enjoyed unceasing popularity, often becoming both a form of political critique and a way of dealing with the complexities of dynamically changing societies.

One of the earliest attempts to map the field of children's literature in "the other Europe" is Sunny Side of Darkness: Children's Literature in Totalitarian and Post-totalitarian Eastern Europe (2005), edited by Jean Webb and Mare Müürsepp. ${ }^{26}$ The collection contains contributions engaging, among others, with the development of YA literature in Poland (Dorota Osięgłowska), the economic and social contexts affecting children's literature in South Eastern Europe (Milena Mileva Blazic), new phenomena in Lithuanian children's literature (Kęstutis Urba), and representations of childhood in post-communist Latvian children's literature (Rudite Rinkevicha). Published three years later, Russian Children's Literature and Culture, edited by Marina Balina and Larissa Rudova, not only demonstrates that Soviet children's literature allowed its creators more creative freedom than the socialist realist literature for

${ }^{21}$ A. Imre, op. cit., p. 81.

${ }^{22}$ Fairy-tale Films beyond Disney: International Perspectives, ed. J. Zipes, P. Greenhill, and K. Magnus-Johnston, New York and London 2016.

${ }^{23}$ M. Balina, B. Beumers, “'To Catch Up and Overtake Disney?' Soviet and Post-Soviet Fairy-Tale Films,” [in:] Fairy-tale Films..., pp. 124-138.

${ }^{24}$ Ibid., p. 135.

25 Ibid., p. 136.

26 Sunny Side of Darkness: Children's Literature in Totalitarian and Post-totalitarian Eastern Europe, ed. J. Webb and M. Müürsepp, Tallinn 2005. 
adults, but also explores the connection between the Soviet legacy and contemporary Russian children's culture. ${ }^{27}$ Most of the contributors focus on different aspects of Soviet culture: Marina Balina traces the beginning of Soviet children's literature and writes about the representation of pre-revolutionary childhood in Soviet literature, Alexander Prokhorov examines cinema for children and young adults, and Anindita Banerjee demonstrates the importance of space flight in children's periodicals. Others study post-Soviet culture: in "From character - building to criminal pursuits: Russian children's literature in transition", Larissa Rudova outlines the evolution of genres and themes in children's literature; Lisa Ryoko Wakamiya demonstrates the relationship between children's literature and cultural institutions; and Jose Alaniz pays particular attention to post-Soviet children's comics. Finally, Look! Polish Picturebook! (2016) by Małgorzata Cackowska, Grażka Lange and Anita Wincencjusz Patyna is a one-of-a-kind study of the history of the picturebook genre in Poland from the 1960s until today. Arguing for the continued influence of older designs on recent approaches to text and image, the authors successfully prove the presence of this genre on the Polish literary market long before the arrival of Western publications at the beginning of the $21^{\text {st }}$ century.

Post-communist children's culture, and in particular children's books, has also been the subject of several shorter studies in English. Children's Literature on the Move: Nations, Translations, Migration, an edited collection published under the aegis of the Irish Society for the Study of Children's Literature contains contributions by Marii Niitra and Justyna Deszcz-Tryhubczak, addressing the role of children's literature in negotiating questions of national history and identity. In "Shared songs, secret codes and Estonian national identity", Niitra focuses on the function of songs as repositories of the Estonian nation in two children's books by Aino Pervik: the use of songs produces "a mental link between the nation's past and contemporary society" ${ }^{28}$ Deszcz-Tryhubczak's chapter, "Kids and fish have no voice'? Recent Children's Literature about the People's Republic of Poland as a platform for participatory historical culture", discusses examples of Polish children's literature as a platform for the development of historical empathy and intergenerational dialogue about the recent history of Poland, and in particular Martial Law and the collapse of communism. ${ }^{29}$ Finally, Marek Oziewicz's essay "Bloodlands fiction: Cultural trauma politics and the memory of Soviet atrocities in Breaking Stalin's Nose, A Winter's Day in 1939 and Between Shades of Gray", published in the 2016 fall issue of International Research in Children's Literature, explores the emergence of historical fiction, including some addressed to young readers, "that engages with the long suppressed collective mem-

${ }^{27}$ Russian Children's Literature and Culture, ed. M. Barina, L. Rudova, New York 2008.

${ }^{28}$ M. Niitra, "Shared songs, secret codes and Estonian national identity," [in:] Children's Literature on the Move. Nations, Translations, Migrations, ed. N. Maguire and B. Rodgers, Dublin 2013, p. 32.

${ }^{29}$ J. Deszcz-Tryhubczak, "Kids and fish have no voice'? Recent children's literature about the People's Republic of Poland as a platform for participatory historical culture," [in:] Children's Literature on the Move..., pp. 134-150. 
ory about Soviet atrocities committed against Eastern European people, including Russian citizens, before, during, and after World War II"30 and whose emergence was possible only after the demise of the communist regime.

These efforts to trace the influences of post-communism and the EuroAmerican West on children's culture in the countries from the former Soviet bloc are examples of the scarce research of this kind available internationally. We believe there is a lot at stake in the endeavour to pay attention to post-1989 children's culture. If " $[\mathrm{t}] \mathrm{he}$ period of post-communist transition (...) is characterized by the uncontrolled play of numerous political, social, economic cultural forces" 31 and is "the New World Disorder" 32 , then how does the post-communist condition shape children's culture, itself a nexus of children's own agency across a spectrum of media and of adults' ideas about childhood and governance of children? Although we cannot cover the subject of post-communist children's culture from a systematic geographical or methodological macro-perspective, we hope that the contributions to this special issue bottom-up interventions from Poland, Ukraine, and the USA - will catalyze further efforts to reduce the paucity of research into cultural production for children across the region.

This special volume of Miscellanea Posttotalitariana Wratislaviensia is monographic in nature and showcases a variety of thought-provoking approaches to children's literature and culture. In Lost in Transitions: Childhood and Child Characters in Post-Yugoslav Playwriting, Gabriela Abrasowicz demonstrates how playwrights from Serbia (Biljana Srbljanović and Milan Marković), Bosnia and Herzegovina (Tanja Šljivar), Montenegro (Maja Todorović), and Kosovo (Jeton Neziraj) focus on micro-social children's stories and points out the influence of political, national, and social transitions on children. In Children of the Post-Communist Era in Contemporary Ukrainian Literature for Young Readers, Tetiana Kachak pays attention to the socio-political transformations in Ukraine and offers a detailed outline of contemporary children's literature devoted to the demise of communism, the transitions in the 1990s, and the recent Euromaidan revolution. Anastasia Ulanowicz's "We are the People": The Holodomor and North American-Ukrainian Diasporic Memory in Marsha Forchuk Skrypuch's "Enough" focuses on the Holodomor, the Ukrainian famine of 1932-1933, which has played a major role in the cultural memory of Ukrainians in diasporic communities in the United States and Canada, but due to ideological reasons was a taboo subject in the USSR and gained widespread recognition only after the collapse of communism. Ulanowicz analyzes the first children's book devoted to this issue, Marsha Forchuk Skrypuch's and Michael Martchenko's Enough

30 M. Oziewicz, Bloodlands Fiction: Cultural Trauma Politics and the Memory of Soviet Atrocities in Breaking Stalin's Nose, A Winter's Day in 1939 and Between Shades of Gray, "International Research in Children's Literature" 2016, vol. 9, no. 2, p. 147.

31 B. Fowkes, The Post-Communist Era: Change and Continuity in Eastern Europe, Basingstoke 1999, p. 4.

32 K. Jowitt, qtd. [in:] B. Fowkes, The Post-Communist Era..., p. 4. 
(2000), which was not published in Ukraine but in North America. In "Be yourself... but don't be a wimp!" Gender Stereotypes in Ukrainian Advice Literature for Girls and Boys, Mateusz Świetlicki examines gender stereotypes in contemporary Ukrainian advice literature for children. By comparing two popular sets of books for boys and girls, he argues that they reinforce patriarchal gender roles based on inequality and sexism. Aleksandra Mochocka's Two Perspectives on the Performative Social Body: Teenage Make-up Routines in Fanfik and the Jeżycjada Cycle addresses the issue of using make-up as an important storyworld in the fiction of two Polish writers, Małgorzata Musierowicz and Natalia Osińska. Mochocka demonstrates that using beauty products in these novels serves as the expression of certain value systems in the communist and post-communist Poland.

Furthermore, this issue includes three reviews of recent scholarly publications on Central and Eastern European children's cultures. In her evaluation of Świat elementarzy. Obraz rzeczywistości w podręcznikach do nauki czytania w krajach bloku radzieckiego, Sylwia Kamińska-Maciąg discusses Joanna Wojdon’s exceptional study on Soviet textbooks. Aniela Radecka looks at Tetiana Kachak's Українська література для дітей та юнацтва: підручник (Ukrainian Literature for Children and Youth: Textbook), one of the first Ukrainian books devoted to children's literature. Finally, Mateusz Świetlicki addresses Sara Pankenier Welds award-winning book Voiceless Vanguard: The Infantilist Aesthetics of the Russian Avant-Garde.

We are thankful to all the contributors to this issue for their commitment to this editorial venture. We would also like to thank the external reviewers for their comments and insightful suggestions.

\section{Bibliography}

Boym, Svetlana. 2001. The Future of Nostalgia. New York: Basic Books.

Cackowska, Małgorzata, Lange, Grażka, and Patyna-Wincencjusz, Anita. 2016. Look! Polish Picturebook! Gdańsk: NCK.

Deszcz-Tryhubczak, Justyna. 2013. "Kids and fish have no voice? Recent Children's literature about the People's Republic of Poland as a platform for participatory historical culture." In Children's Literature on the Move. Nations, Translations, Migrations. edited by Nora Maguire and Beth Rodgers. Dublin: Four Courts Press: 134-150.

Fairy-tale Films beyond Disney: International Perspectives. 2016. edited by Jack Zipes, Pauline Greenhill, and Kendra Magnus-Johnston. New York and London: Routledge.

Fowkes, Ben. 1999. The Post-Communist Era: Change and Continuity in Eastern Europe. Basingstoke: Palgrave.

Huyssen, Andreas. 2000. "Present pasts: Media, politics, amnesia." Public Culture 12 (1): 21-38.

Imre, Anikó. 2009. Globalization and the Transformation of Media Cultures in the New Europe. Cambridge, MA: The MIT Press.

Jenkins, Henry. 2006. Fans, Bloggers and Gamers: Media Consumers in a Digital Age. New York: New York University Press.

Lazarus, Neil. 2012. "Spectres haunting: Postcommunism and postcolonialism." Journal of Postcolonial Writing 48 (2): 117-129. 
Niitra, Mari. 2013. "Shared songs, secret codes and Estonian national identity." In Children's Literature on the Move. Nations, Translations, Migrations. edited by Nora Maguire and Beth Rodgers. Dublin: Four Courts Press: 32-43.

Oziewicz, Marek. 2016. "Bloodlands fiction: Cultural trauma politics and the memory of Soviet atrocities in Breaking Stalin's Nose, A Winter's Day in 1939 and Between Shades of Gray."International Research in Children's Literature 9 (2): 146-161.

Rupnik, Jacques. 1988. The Other Europe. London: Weidenfeld and Nicholson.

Russian Children's Literature and Culture. 2008. edited by Marina Balina and Larissa Rudova. New York: Routledge.

Sowa, Marzena, and Sylvain Savoia. 2011. Nie ma wolności bez solidarności. Warszawa: Egmont.

Sunny Side of Darkness: Children's Literature in Totalitarian and Post-totalitarian Eastern Europe. 2005. edited by Jean Webb and Mare Müürsepp. Tallinn: TLÜ Kirjastus.

Tlostanova, Madina. 2012. "Postsocialist $\neq$ postcolonial? On post-Soviet imaginary and global coloniality." Journal of Postcolonial Writing 48 (2): 130-142.

Todorova, Maria. 2010. "Introduction: From utopia to propaganda and back." In Post-Communist Nostalgia, edited by Maria Todorova and Zsuzsa Gille. Berghahn Books: New York and London. 